\title{
Capacity Assessment and Design of CFRP-Strengthened Steel Channel Columns
}

\author{
Sreedhar Kalavagunta ${ }^{1 *}$, Sivakumar Naganathan ${ }^{2}$ and Kamal Nasharuddin Bin Mustapha ${ }^{3}$ \\ ${ }^{1}$ Universiti Tenaga Nasional, Jalan IKRAM-UNITEN, 43000, Kajang, Selangor, Malaysia; \\ sreedhar.bala@gmail.com \\ ${ }^{2}$ Civil Engineering, Universiti Tenaga Nasional, Jalan IKRAM-UNITEN, 43000, Kajang, \\ Selangor, Malaysia; SivaN@uniten.edu.my \\ ${ }^{3}$ Civil Engineering, Universiti Tenaga Nasional, Jalan IKRAM-UNITEN, 43000, Kajang, \\ Selangor, Malaysia; kamal@uniten.edu.my
}

\begin{abstract}
This paper presents a design method (BS5950-5) to predict the allowable load carrying capacity of cold formed steel channel section strengthened by carbon fiber reformed polymer composites applied to the web of the beam. A specimen is presented to illustrate the proposed design approach. The validity of the proposed design method has been verified by comparing with the experimental test results. A series of compression tests were conducted on plain and CFRP strengthened steel sections of different geometries. This paper also contains the consequences obtained by comparing the strengths of plain and CFRP strengthened steel columns using compression test. The findings showed that the strength of CFRP strengthened steel columns were up to $10 \%$ greater than plain cold form steel sections.
\end{abstract}

Keywords: CFRP, CFRP Strengthening, Axial Compression, Cold Formed Steel.

\section{Introduction}

The use of carbon fiber reinforced polymers (CFRP) in strengthening structural members is rapidly gaining in past two decades. When compared to conventional steel reinforcement or concrete encasements CFRP are light in weight, has high strength-to-weight ratio, ease to handling and application, no need for heavy lifting and handling equipments and corrosion resistance. Some benefits mentioned above have proved CFRP to be advantageous to repair, retrofit and rehabilitation of civil engineering structures.

Several studies have been conducted on the use of CFRP sheets, like non-linear behavior and load carrying capacity of CFRP strengthened lipped channel steel [1-2], web crippling [3], tubular beams and columns
[4-5], Axial capacity and design of SHS steel section strengthened with CFRP [6], web buckling [7]. Proper installation of CFRP is essential in ensuring bonding between CFRP materials and metallic structures. In previous papers [8-12], the authors showed significant strength enhancement of CFRP strengthened steel plate by investigating bond characteristics between CFRP laminate and steel by experimental, theoretical and finite element analysis. Recently, a comprehensive state-ofthe-art review of FRP-strengthening of steel structures was published by Zhao and Zhang [13]. The researchers showed the behavior in terms of load- deflection, load-strain, failure patterns and structural ductility. All investigations showed a considerable increase in ultimate load carrying capacity from 10 to $20 \%$ with a good energy absorption capability.

* Corresponding author:

Sreedhar Kalavagunta (sreedhar.bala@gmail.com) 


\section{Material Properties and Test Specimens}

The channel lipped cold formed steel sections used in the tests were produced by BlueScope Malaysia SDN BHD. A section identification number is assigned to each channel section as show in Table1. The test specimens yield stress of $550 \mathrm{Mpa}$ and modules of elasticity of $200 \mathrm{Gpa}$ were used in this study. Unidirectional high-strength carbon fiber sheets namely MBrace CF 130 of $3790 \mathrm{MPa}$ ultimate tensile strength $230 \mathrm{Gpa}$ elastic modulus with a thickness of $0.176 \mathrm{~mm}$ were used in this investigation. The surface of the steel was ground with an abrasive disc and then solvent cleaned to obviate any contamination on the surface and to promote good adhesive Figure 2 (a). Carbon fiber sheet was prepared according to the required dimensions and mixed with high-modulus epoxy adhesive MC-Bauchemie was smeared uniformly on the surface of the fiber sheet. The composite sheet was then placed around the exposed external surface of the column and gradually pressed along the fiber axis.

The specimens prepared length is greater than three times flat width of the section and its length/radius of gyration in the direction of the least radius of gyration was kept to less than 50. It is done to prevent failure of the column due to column flexural buckling rather than local buckling. Lipped channel sections was tested with various lengths $500 \mathrm{~mm}, 600 \mathrm{~mm}$ and $700 \mathrm{~mm}$, depth ranging from $75 \mathrm{~mm}$ to $100 \mathrm{~mm}$ and thicknesses 0.6 to $1 \mathrm{~mm}$ are presented in Table 1 .

\section{Experimental Set-up and Procedures}

Concentric compression tests were conducted on channel section and CFRP strengthened channel section, the setup of the section and the test rig are shown in Figure 1. A low voltage displacement transducer is placed on top surface of the test rig parallel to test specimen to observe the vertical deflection.

A total 27 plain and 27 CFRP strengthened lipped channel section specimens referred in Figure 2(b) were tested, the experimental critical buckling load was determined using axial load $\mathrm{P}$, plotted against the strain gauge readings and the point of the curve at which the rate of strain decreases rapidly was used to indicate the critical buckling load. Most of the members failed due to local buckling as shown in Figure 3 .

All steel columns were designed in order to increase slenderness of the cross section. The specimens range from $500 \mathrm{~mm}$ to $700 \mathrm{~mm}$. To ensure that the two supporting ends were parallel to each other and perpendicular to the loading axis, they were wire eroded normal to the loading axis. This ensured full contact between specimen and steel end plates.

\section{Design Rules}

In recent years there have been a number of studies related to CFRP strengthening of steel structures, particularly in the field of thin-walled steel structures. There is limited information on design methods for CFRP strengthened steel structures, so this is an attempt to propose design method for CFRP strengthened channel section subjected to pure axial load Equation 3. The proposed method is developed based on British Standards BS5950-Part5 [14] with following assumptions:

- Slenderness of the composite plate is due to perfect bond between steel and CFRP.

- CFRP play an important role in elastic buckling but not on strength.

- Gross area is considered as effective area for short columns.

Table 1. Section Dimensions and Properties

\begin{tabular}{|c|c|c|c|c|c|c|c|c|c|}
\hline Component & $\begin{array}{l}\text { Thickness } \\
(\mathrm{mm})\end{array}$ & $\begin{array}{l}\text { Yield Stress } \\
\text { (Mpa) }\end{array}$ & $\begin{array}{l}\text { Area } \\
\left(\mathrm{mm}^{2}\right)\end{array}$ & $\begin{array}{l}I_{x x} x 10^{4} \\
\left(\mathrm{~mm}^{4}\right)\end{array}$ & $\begin{array}{l}I_{y y} x 10^{4} \\
\left(\mathrm{~mm}^{4}\right)\end{array}$ & $\begin{array}{l}\text { Section } \\
\text { Modulus, } \mathrm{Z}_{\mathrm{x}} \\
\mathrm{x} 10^{3}\left(\mathrm{~mm}^{3}\right)\end{array}$ & $\begin{array}{l}\text { Section } \\
\text { Modulus, } \mathrm{Z}_{\mathrm{y}} \\
\mathrm{x} 10^{3}\left(\mathrm{~mm}^{3}\right)\end{array}$ & $\begin{array}{l}\text { Radius of } \\
\text { Gyration } R_{x} \\
(\mathrm{~mm})\end{array}$ & $\begin{array}{l}\text { Radius of } \\
\text { Gyration } \mathrm{R}_{\mathrm{y}} \\
(\mathrm{mm})\end{array}$ \\
\hline C7510 & 1 & 550 & 137 & 12.2 & 2.85 & 3.25 & 1.02 & 29.84 & 12.67 \\
\hline $\mathrm{C} 7512$ & 1.2 & 550 & 204 & 18.9 & 5.2 & 5.14 & 1.84 & 30.43 & 15.96 \\
\hline C100 & 1 & 550 & 216 & 36.4 & 7.55 & 7.13 & 2.19 & 41.1 & 18.7 \\
\hline
\end{tabular}



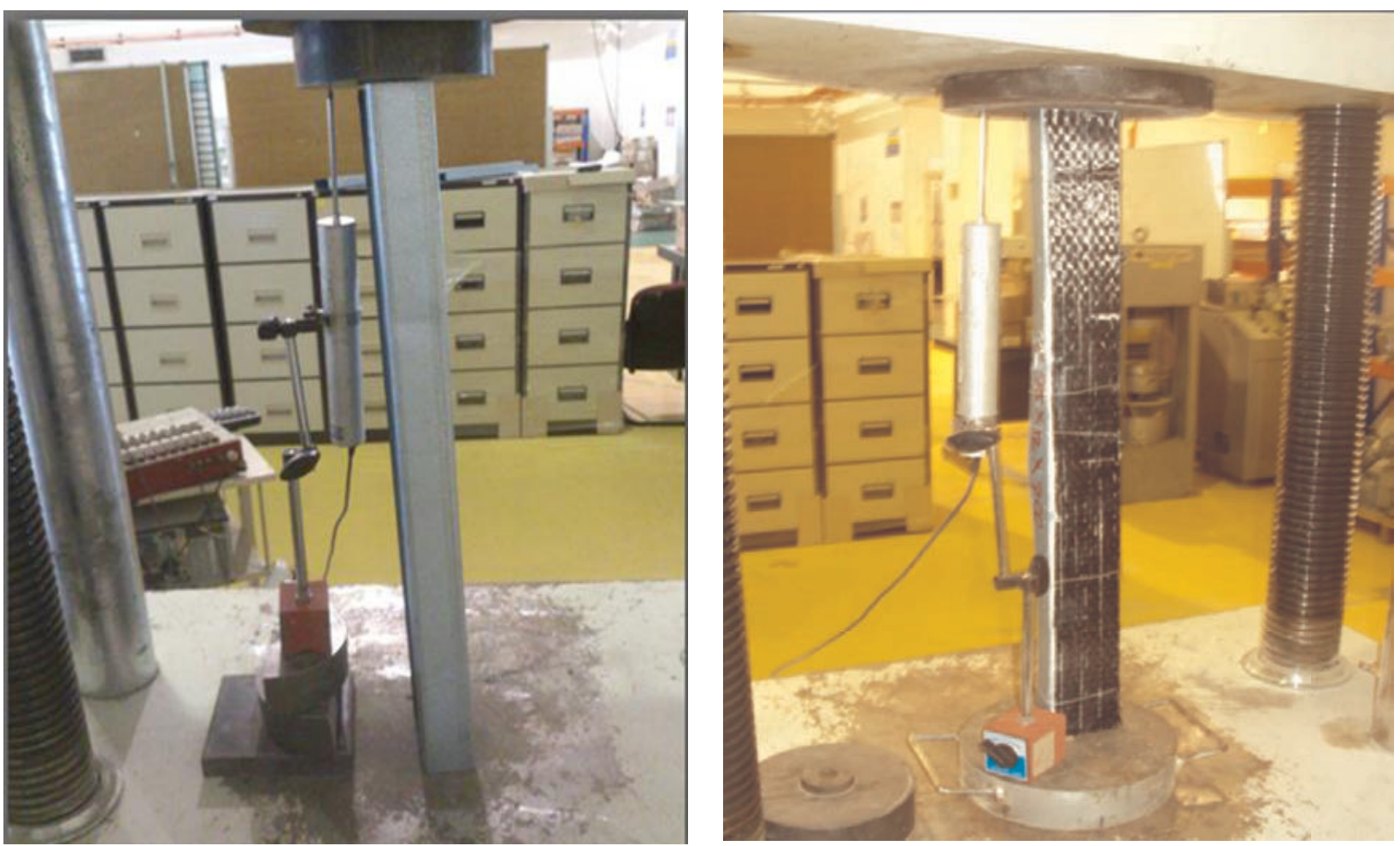

Figure 1. Test set up (a) plain cold formed steel (b) CFRP Strengthened cold formed steel.
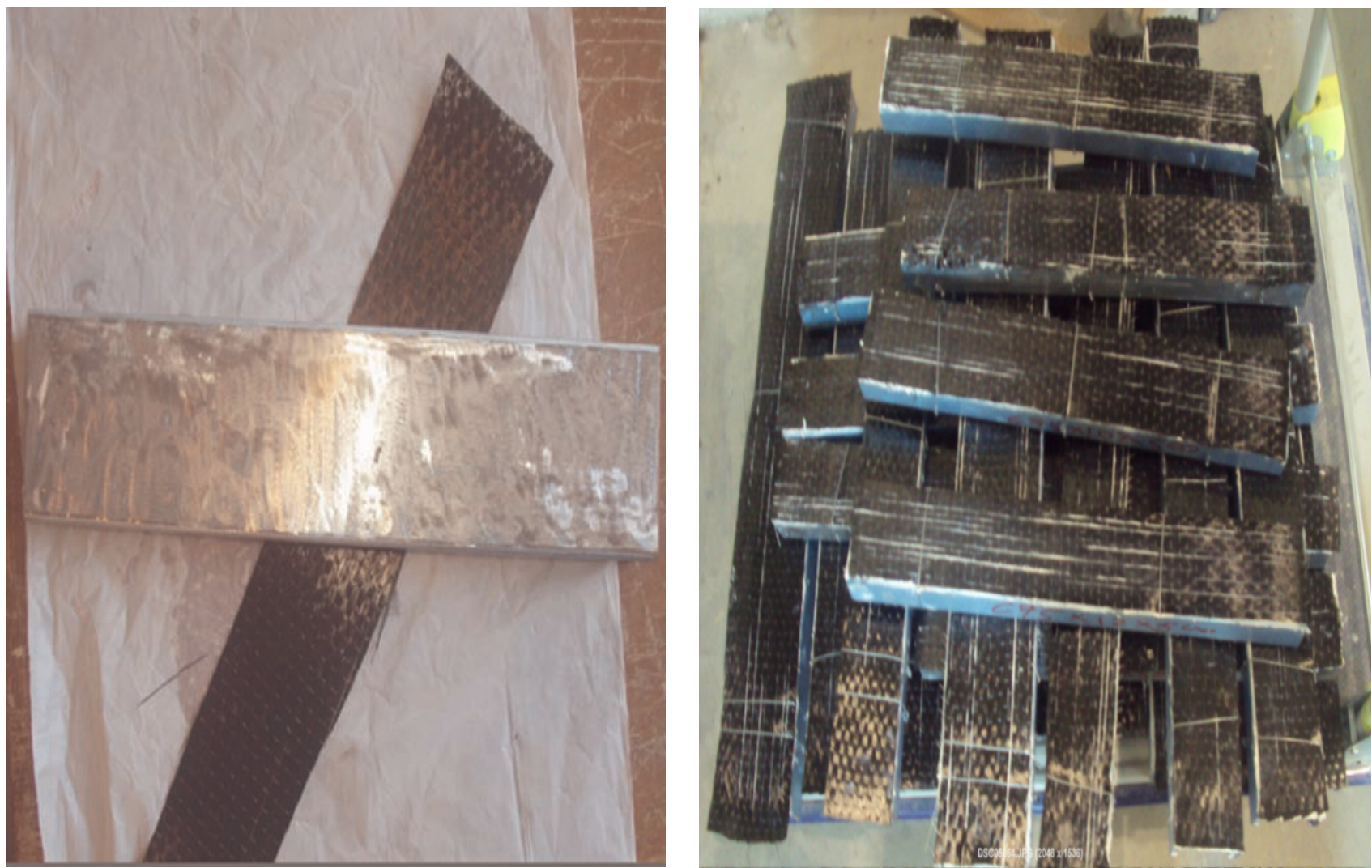

Figure 2. (a) Surface preparation (b) Prepared test specimens. 


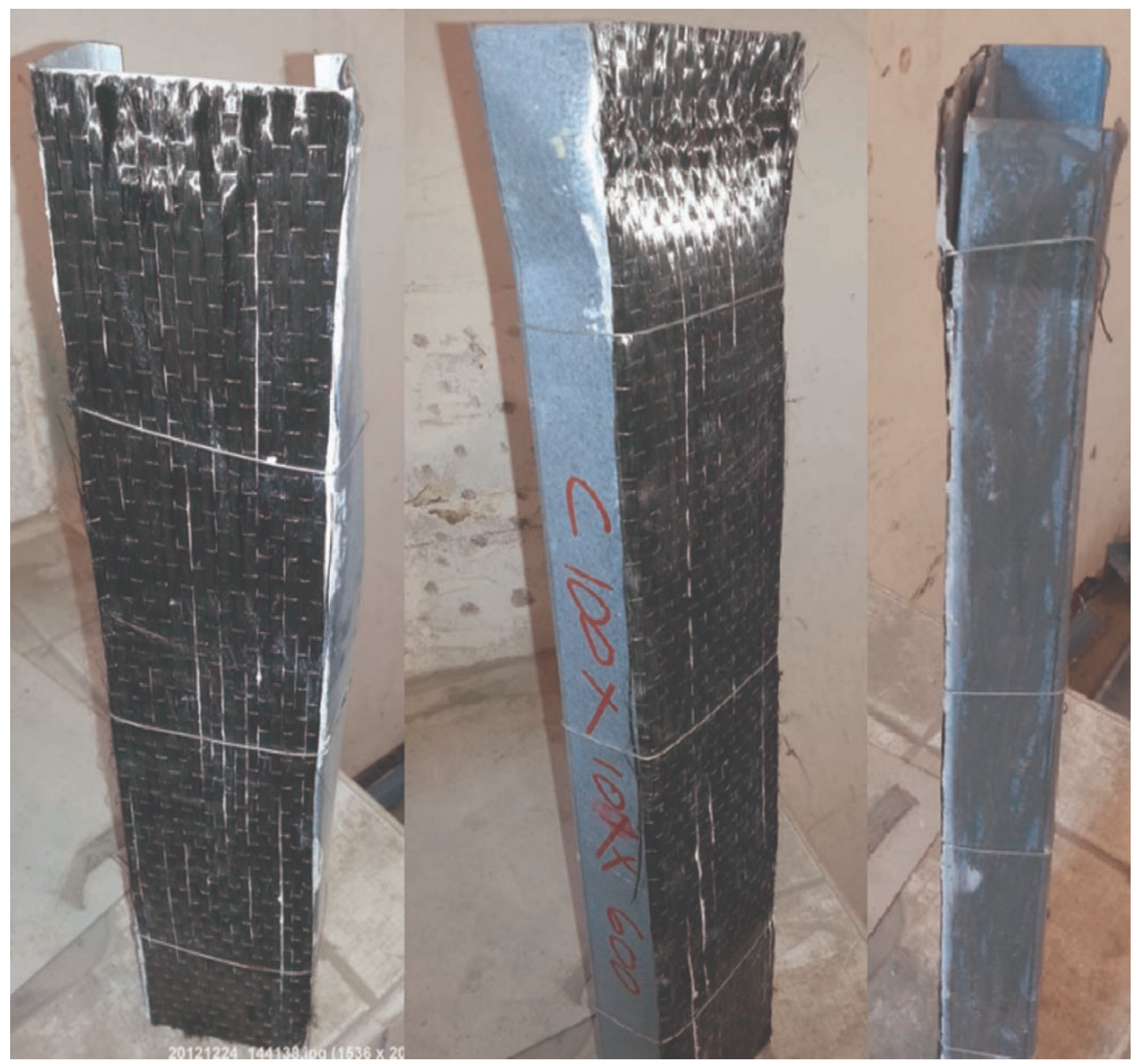

Figure 3. (a) Web Buckling, (b) Local buckling, (c) Local buckling with CFRP bonding failure.

The ultimate load of short strut is obtained from the below equation.

$$
P_{u}=A_{e f f} P_{c}^{\prime}
$$

The effective area, $\mathrm{A}_{\text {eff }}$ of the cross sections is determined by summing up the values of effective areas for all the individual elements based on the effective width method.

Total thickness of CFRP layered plate $\left(t_{t}\right)$ is taken as the sum of the thicknesses of CFRP $\left(t_{c f}\right)$ and steel plate $\left(t_{s}\right)$, neglecting adhesive layer thickness as, it is weak in strength Equation (1). The elastic modulus of the CFRP with steel is determined from the modular ratio concept Equation (2),

$$
\begin{gathered}
t_{t}=\left(t_{c f}\right)+t_{s} \\
E_{c f p}=\frac{E_{s} t_{s}+E_{c f} t_{c f}}{t_{s}+t_{c f}}
\end{gathered}
$$

The ultimate load is evaluated by allowing the interaction with bending and compression using the equation available 
in BS5950-5 section 6.2.4. Following that approach, the modified design load is evaluated from

$$
P_{c f r p}^{\prime}=\frac{M_{c} P_{c}}{\left(M_{c}+P_{c} e_{s}\right)}
$$

Where,

$M_{c}$ is the moment capacity.

$P_{c}$ is the buckling resistance under axis load.

$\mathrm{e}_{s}$ is the distance between the effective centroid and actual centroid of the cross section, since cross section wrapped with CFRP the value conservatively assumed as unity.

Moment capacity $\mathrm{M}_{\mathrm{c}}$ determined on the basis of a limiting compressive stress in the webs, $\mathrm{p}_{\mathrm{o}}$ as per section 5.2.2.2 of BS5950-5.

$$
p_{o}=\left\{1.13-0.0019 \frac{D_{w}}{t_{t}}\left(\frac{Y_{s}}{280}\right)^{1 / 2}\right\} p_{y} \leq p_{y}
$$

Where,

$D_{w}$ is the section depth or twice the depth of the compression zone.

$Y_{s}$ is the material yield strength in Newton per square millimeter $\left(\mathrm{N} / \mathrm{mm}^{2}\right)$

$t_{t}$ is the web thickness in millimeters $(\mathrm{mm})$.

$p_{y}$ is the design strength in Newton per square millimeter $\left(\mathrm{N} / \mathrm{mm}^{2}\right)$

The buckling resistance under axial load, $\mathrm{P}_{\mathrm{c}}$, may be obtained from the following

$$
P_{c}=\frac{P_{E} P_{c s}}{\varnothing+\sqrt{\varnothing^{2}-P_{E} P_{c s}}}
$$

where,

$$
\varnothing=\frac{P_{C S}+(1+\eta) P_{E}}{2}
$$

$P_{E}$ is the minimum elastic flexural buckling load and is equal to $\frac{\pi^{2} E_{c f r p} I}{L_{E}^{2}}$.

$\mathrm{E}_{c f r p}$ is the modulus of elasticity of composite section.

I is the second moment of area of the cross-section about the critical axis.

$\mathrm{L}_{E}$ is the effective length of the member about the critical axis.

$\eta$ is the Perry coefficient, such that:

$$
\begin{aligned}
& \text { for } \mathrm{L}_{\mathrm{E}} / \mathrm{r} \leq 20, \eta=0 \\
& \text { for } \mathrm{L}_{\mathrm{E}} / \mathrm{r}>20, \eta=0.002\left(\mathrm{~L}_{\mathrm{E}} / \mathrm{r}-20\right)
\end{aligned}
$$

where,

$r$ is the radius of gyration of the gross cross-section corresponding to $\mathrm{P}_{\mathrm{E}}$

$$
P_{u_{-} c r p}=A_{e f f} P_{c f r p}^{\prime}
$$

$\mathrm{P}_{u_{-} \text {cfrp }}$ is allowable compression stress modified equation as per BS5950-5:1998 section 6.2.4.

\section{Comparisons of Predicted Ultimate Capacity with Experimental Ultimate Capacity}

The failure modes of tested specimens are shown in Figure 3 , clearly indicates evident of local buckling. The ultimate capacity of plain cold formed steel based on BS5950-5 and experimental results are compared in Table 2. The ultimate capacity of CFRP strengthened sections using proposed design models described in Section 3 is compared with experimental test results in Table 3 , where reasonable agreement is obtained. These results show that the proposed analytical method predicts the ultimate load appropriately. The uneven difference between the predicted ultimate load vs experimental results and modes of failures in these columns, show that the increase in strength due to CFRP depends on effectiveness of bond. The comparison between plain and CFRP strengthened cold formed steel also presented in Table 4 . Similar to the previous studies, the compression strength and stiffness of the CFRP strengthened cold formed steel columns increased compared to plain cold formed steel columns.

\section{Conclusions}

A series of compression tests on steel columns with and without reinforced by high-strength CFRP sheets was conducted to study the pure axial behavior and strength of the columns. The experiment results suggest that the capacity of CFRP strengthened lipped channel sections were up to $10 \%$ greater than plain steel columns. The experimental ultimate capacities were compared with the BS5950-5 provisions. A reasonable agreement was obtained. Based on discussions presented in this paper, it is recommended that further research should address the following issues. 
Table 2. Axial Compression tests results of cold formed steel members: Experimental vs. Theoretical

\begin{tabular}{lcccc}
\hline Section & FY Mpa & $\begin{array}{c}\text { Ultimate Axial Compression } \\
\text { Capacity-Experimental-kN }\end{array}$ & $\begin{array}{c}\text { Ultimate Axial Compression } \\
\text { Capacity - Theoretical -kN }\end{array}$ & $\begin{array}{c}\text { \% of difference } \\
\text { Experimental /Theoretical }\end{array}$ \\
\hline C7510x500mm & 550 & 57.97 & 51.98 & 11.52 \\
C7510x600mm & 550 & 57.88 & 51.82 & 11.69 \\
C7510x700mm & 550 & 56.75 & 51.27 & 10.68 \\
C7512x500mm & 550 & 72.65 & 66.75 & 8.83 \\
C7512x600mm & 550 & 71.08 & 66.51 & 6.87 \\
C7512x700mm & 550 & 69.5 & 65.80 & 5.62 \\
C10010x500mm & 550 & 68.5 & 59.98 & 14.20 \\
C10010x600mm & 550 & 67.9 & 59.86 & 13.43 \\
C10010x700mm & 550 & 66.9 & 59.72 & 12.02 \\
\hline
\end{tabular}

Table 3. Axial Compression tests results of CFRP Strengthened cold formed steel members: Experimental vs. Theoretical

\begin{tabular}{lccc}
\hline Section & FY Mpa & $\begin{array}{c}\text { Ultimate Axial Compression } \\
\text { Capacity-Experimental-kN }\end{array}$ & $\begin{array}{c}\text { Ultimate Axial Compression } \\
\text { Capacity - Theoretical -kN }\end{array}$ \\
\hline C7510x500mm & 550 & 64.26 & 57.80 \\
C7510x600mm & 550 & 64.01 & 57.79 \\
C7510x700mm & 550 & 64.05 & 57.37 \\
C7512x500mm & 550 & 80.05 & 78.57 \\
C7512x600mm & 550 & 79.64 & 78.5 \\
C7512x700mm & 550 & 78.92 & 78.06 \\
C10010x500mm & 550 & 74.58 & 72.88 \\
C10010x600mm & 550 & 74.23 & 72.08 \\
C10010x700mm & 550 & 73.96 & 72.0 \\
\hline
\end{tabular}

Table 4. Axial Compression tests results of CFRP Strengthened cold formed steel members vs. Plain Cold formed steel

\begin{tabular}{lcccc}
\hline Section & FY Mpa & $\begin{array}{l}\text { Plain Cold formed steel } \\
\text { Ultimate Axial Compression } \\
\text { Capacity-Experimental-kN }\end{array}$ & $\begin{array}{l}\text { CFRP Strengthened steel } \\
\text { Ultimate Axial Compression } \\
\text { Capacity-Experimental-kN }\end{array}$ & $\begin{array}{c}\text { \% of increase in strength for } \\
\text { CFRP strengthened sections. }\end{array}$ \\
\hline C7510x500mm & 550 & 57.97 & 64.26 & 10.08 \\
C7510x600mm & 550 & 57.88 & 64.01 & 12.21 \\
C7510x700mm & 550 & 56.75 & 64.05 & 14.68 \\
C7512x500mm & 550 & 72.65 & 80.05 & 10.60 \\
C7512x600mm & 550 & 71.08 & 79.64 & 10.05 \\
C7512x700mm & 550 & 69.5 & 78.92 & 11.15 \\
C10010x500mm & 550 & 68.5 & 74.58 & 14.64 \\
C10010x600mm & 550 & 67.9 & 74.23 & 13.67 \\
C10010x700mm & 550 & 66.9 & 73.96 & 13.69 \\
\hline Average Increase of Strength due to CFRP strengthening & & 10.98 \\
\hline
\end{tabular}


- The effect of epoxy should be considered for CFRP-reinforced steel columns in order to ensure the effective design of CFRPreinforced steel columns.

- Steel surface preparation and characterization to develop a widely accepted procedure.

- De-bonding failures.

\section{References}

1. Silvestre N, Young B et al. (2008). Non-linear behavior and load-carrying capacity of CFRP-strengthened lipped channel steel columns, Engineering Structures, vol 30(10), 2613-2630.

2. Silvestre N, Camotim D et al. (2009). On the use of the EC3 and AISI specifications to estimate the ultimate load of CFRP-strengthened cold-formed steel lipped channel columns, Thin-Walled Structures, vol 47(10), 1102-1111.

3. Wu C, Zhao X et al. (2011). Design rules for web crippling of CFRP strengthened aluminum rectangular hollow sections, Thin-Walled Structures, vol 49(10), 1195-1207.

4. Haedir J, Zhao X -L et al. (2010). Analysis of CFRP externallyreinforced steel CHS tubular beams, Composite Structures, vol 92(12), 2992-3001.

5. Haedir J and Zhao X -L (2011). Design of short CFRPreinforced steel tubular columns, Journal of Constructional Steel Research, vol 67(3), 497-509.
6. Bambach M R, Jama H H. et al. (2009). Axial capacity and design of thin-walled steel SHS strengthened with CFRP, Thin-Walled Structures, vol 47(10), 1112-1121.

7. Zhao X and Al-Mahaidi R (2009). Web buckling of light steel beams strengthened with CFRP subjected to end-bearing forces, Thin-Walled Structures, vol 47, 1029-1036.

8. Fawzia S, Zhao X et al. (2010). Bond-slip models for double strap joints strengthened by CFRP, Composite Structures, vol 92(9), 2137-2145.

9. Lanier B, Schnerch D et al. (2009). Behavior of steel monopoles strengthened with high-modulus CFRP materials, Thin-Walled Structures, vol 47(10), 1037-1047.

10. Haghani R (2010). Analysis of adhesive joints used to bond FRP laminates to steel members a numerical and experimental study, Construction and Building Materials, vol 24(11), 2243-2251.

11. Al-Zubaidy H, Al-Mahaidi R et al. (2012). Experimental investigation of bond characteristics between CFRP fabrics and steel plate joints under impact tensile loads, Composite Structures, vol 94(2), 510-518.

12. Wua C, Zhao X et al. (2012). Bond characteristics between ultra-high modulus CFRP laminates and steel, Thin-Walled Structures, vol 51, 147-157.

13. Zhao $X$ and Zhang L (2007). State-of-the-art review on FRP strengthened steel structures, Engineering Structural, vol 29(8), 1808-1823.

14. British Standard BS5950-5, (1998). Structural use of steelwork in building-Part 5, Code of practice for design of cold formed thin gauge sections. British Standards Institution, UK. 